Editorial

\title{
Editorial for Quantitative Geomorphology Special Issue
}

\author{
Dario Gioia \\ Istituto per i Beni Archeologici e Monumentali (IBAM), Consiglio Nazionale delle Ricerche, C.da S. Loja, \\ I-85050 Tito Scalo (Potenza), Italy; dario.gioia@cnr.it
}

Received: 10 December 2018; Accepted: 10 December 2018; Published: 12 December 2018

In recent years, DEM- and GIS-supported analysis of landscape has become an important research field in many geomorphological applications, which aim to model surface processes in a variety of geomorphic environments and at different spatial and temporal scales. Large availability of both global high-resolution DEMs and efficient GIS tools has promoted the development and application of quantitative techniques of extraction of geomorphological parameters and models, which support traditional geomorphological approaches to solve the issue of landscape characterization and evolution. The Special Issue "Quantitative Geomorphology" collects eight papers that highlight the usefulness of quantitative analyses of the landscape to extract information about the: (i) Geomorphological evolution of coastal and continental landscapes, (ii) development of erosion models; (iii) semi-automatic classification of landforms, and its usefulness in geomorphological applications.

Pennetta (2018) [1] introduces a morpho-sedimentary analysis of a highly-urbanized coast of southern Italy (i.e., the Gulf of Naples). Classical geomorphological and sedimentary analysis has been integrated by meteomarine data, morphobathymetic surveys, and multitemporal analyses of aerial photos and topographic maps. Results highlight that the construction of the Torre Annunziata harbour in 1871 promoted a relevant modification of long-term natural evolution and longshore sediment distribution of the coastal area.

A new prediction model to estimate the sediment yield in Italian ungauged river basins has been proposed by Grauso et al. (2018) [2]. The Authors developed a statistical correlation between suspended sediment yield data from 30 Italian rivers, and several morphometric parameters of the drainage basins such as the catchment elevation range, the density of stream hierarchical anomaly, and the stream channel slope ratio. The derived regression equation can represent a simple but effective tool to extract sediment yield in catchments of Italy.

Nico et al. (2018) [3] investigated the capability of the ground surface to generate Interferometric Synthetic Aperture Radar Persistent Scatterers (InSAR-PS) in relation to the landscape features. Frequency distribution of persistent scatterers has been estimated in a non-urban environment of Portugal in order to infer the relationships among PS density, lithology, and landscape morphometry. PS distribution is strongly controlled by lithology, slope angle and aspect, and this relationship can be useful to estimate the expected PS density in the different geological and geomorphological settings.

An interesting unsupervised mapping method of regolith based on readily available landform metrics (i.e., Topographic Position Index, TPI and Slope Position Classes, SPC) and gamma-ray spectrometry data has been developed by Caruso et al. (2018) [4]. Such an approach has been tested in the southern Gawler Ranges, South Australia. The good accordance between the derived regolith-landform classification and traditional mapping testifies the rising role of semi-automatic classification of landforms in many geomorphological applications.

The paper by Gioia et al. (2018) [5] investigated the Late Quaternary morphotectonic evolution of the frontal sector of the southern Apennines chain through a morphometric analysis of both drainage network and topography. Swath profiles, preferential orientation of channels and river profile 
anomalies, suggest an active tectonic control of the blind thrust of the chain on the development and evolution of the drainage network.

Sarma and Acharjee (2018) [6] introduced a large amount of data about the spatial and temporal distribution of width and braiding index of the Brahmaputra River, Asia. Morphometric indexes have been evaluated using topographic maps of 1912-1928 and 1963-1975, and dry season satellite data of 1996, 2000, 2007, and 2009 in order to infer the external factor controls and possible management plans. Moreover, changes in channel morphology have been discussed in relation to sediment input modification induced by strong earthquakes and large-scale landslides.

A detailed geomorphological analysis of an impressive landslide has been carried out by Lazzari and Piccarreta (2018) [7]. Predisposing and triggering factors of the large landslide event occurring near to Montescaglioso town, southern Italy on 3 December 2013 have been investigated by a geomorphological survey, multitemporal photointerpretation, slope stability model, and rainfall analysis. Acquired data highlighted the relevant role of anthropogenic modification on the slope stability.

Marrucci et al. [8] analysed the longitudinal profiles of the river channels in the Stura di Demonte Valley (Maritime Alps) to identify the spatial distribution of knickpoints and to characterize their origins. Detailed analysis of the relationships between knickpoint location and local geological/geomorphological factors suggests that the development and migration of river profile anomalies are controlled by multiple perturbing factors such as tectonic movements, quaternary glaciations, river captures, variable lithology, and base-level changes.

The results presented in the papers of the Special Issue well summarize the relevant role of quantitative geomorphological analysis to solve the issue of landscape evolution. All the contributions of the volume provide an advance of knowledge of the high potential of the quantitative geomorphology in the multidisciplinary analysis of the geomorphic processes acting in complex geological environments.

Conflicts of Interest: The author declares no conflict of interest.

\section{References}

1. Pennetta, M. Beach Erosion in the Gulf of Castellammare di Stabia in Response to the Trapping of Longshore Drifting Sediments of the Gulf of Napoli (Southern Italy). Geosciences 2018, 8, 235. [CrossRef]

2. Grauso, S.; Pasanisi, F.; Tebano, C.; Grillini, M.; Peloso, A. Investigating the Sediment Yield Predictability in Some Italian Rivers by Means of Hydro-Geomorphometric Variables. Geosciences 2018, 8, 249. [CrossRef]

3. Nico, G.; Oliveira, S.; Catalão, J.; Zêzere, J.L. Generation of Persistent Scatterers in Non-Urban Areas: The Role of Microwave Scattering Parameters. Geosciences 2018, 8, 269. [CrossRef]

4. Caruso, A.S.; Clarke, K.D.; Tiddy, C.J.; Delean, S.; Lewis, M.M. Objective Regolith-Landform Mapping in a Regolith Dominated Terrain to Inform Mineral Exploration. Geosciences 2018, 8, 318. [CrossRef]

5. Gioia, D.; Schiattarella, M.; Giano, S. Right-Angle Pattern of Minor Fluvial Networks from the Ionian Terraced Belt, Southern Italy: Passive Structural Control or Foreland Bending? Geosciences 2018, 8, 331. [CrossRef]

6. Sarma, J.; Acharjee, S. A Study on Variation in Channel Width and Braiding Intensity of the Brahmaputra River in Assam, India. Geosciences 2018, 8, 343. [CrossRef]

7. Lazzari, M.; Piccarreta, M. Landslide Disasters Triggered by Extreme Rainfall Events: The Case of Montescaglioso (Basilicata, Southern Italy). Geosciences 2018, 8, 377. [CrossRef]

8. Marrucci, M.; Zeilinger, G.; Ribolini, A.; Schwanghart, W. Origin of Knickpoints in an Alpine Context Subject to Different Perturbing Factors, Stura Valley, Maritime Alps (North-Western Italy). Geosciences 2018, 8, 443. [CrossRef] 